\title{
Relevance of Monolingualism on Trilingualism and Achievement in Language Learning among English Students of Nile University of Nigeria, Abuja, Nigeria
}

\author{
BELLO, Yekeen \\ Department of English Studies, Faculty of Arts and Social Sciences, Nile University of Nigerian \\ Abuja, Nigeria, 681, Cadastral Zone C-Oo, Research and Institution Area \\ Jabi Airport Road Bypass, Abuja
}

*Corresponding Author: BELLO, Yekeen, Department of English Studies, Faculty of Arts and Social Sciences, Nile University of Nigerian, Abuja

Received Date: 20-06-2017

Accepted Date: 21-07-2017

Published Date: 29-07-2017

\begin{abstract}
The study took a look at the relevance of Monolingualism on trilingualism vis-à-vis achievement in language learning among students of English Studies department of Nile University of Nigeria, Abuja. The study was carried out to test the presupposition whether or not monolingualism has effects on trilingualism and achievement in language learning. The study is a descriptive survey type, and has its population as all the 30 students of the English Studies department. A stratified random sampling technique which consisted of 10 monolingual learners of English, 10 bilingual learners of English and 10 trilingual learners of English was used. The sample featured British students that are studying English (monolingual learners of English), Hausa students who are studying English (bilingual learners of English) as well as Turkish students who are studying English (bilingual learners of English), and Igbo students that speak Yoruba and Hausa languages in addition to their native language and are also studying English (trilingual learners of English). A 20-item researcher-designed questionnaire was used. The instrument, having been subjected to test re-test statistical technique, yielded a reliability index of 0. 54 at 0.05 alpha level of significance. Research questions 1-6 were answered using Mean and Standard Deviation statistics while hypotheses 1-6 were tested using t-test statistics. Percentile statistic was used to determine the frequencies of monolingual, bilingual and trilingual learners of English. The findings of the analyses indicate that grammatical performance of monolingual, bilingual and trilingual learners of English was good while oral reading performance of monolingual, bilingual and trilingual learners of English was only average. We are able to draw conclusion from the findings that literally, L1 is seen to aid the learning of L2, then L2 or the combination of LI and L2 facilitates the learning of L3 which in turn facilitates general academic achievement. With this conclusion, it was recommended that Federal government should look into the concept of multilingualism with a view to making it an achievable project for national and international intelligibility that would promote national development; Federal Ministry of Education should enforce it that each Nigerian child should have a certificate of one of the Nigerian languages other than his own native or indigenous language, and make books on Nigeria languages cheaper and available, among other recommendations.
\end{abstract}

Keywords: Monolingualism, bilingualism, trilingualism, millionaires, centimils, deca-millionaires, achievement in language learning, language hierarchy and mother tongue.

\section{INTRODUCTION}

Language as viewed by Areje (1988) in Oke (2000) helps in giving discussions, directives and decisions to some measures of authority and persuasiveness. In another instance, Encyclopedia Britannica defines language as a system of conventional spoken or written symbols by means of which human beings and members of a social group and participants in a community communicate. Lado (1964) asserts that freeborn stimuli make language instrument of thought and expression for all normal human beings. Lado points further that it is through language that man gets to known about his environment and reasons about it, and consequently creates meaning for his environment, this implies that language and thinking go hand in glove. Even though Piaget (1968) points that "although" thought does not involve language, "thought" is useless in fact, it is better not formulated if a means of its expression is lacking. It could therefore be 
inferred that without language, there would be no thought because thinking is done in language. In essence, language in its real sense is an artificial and consciously organised way of control by the use of symbol or convention which involves the notion of meanings.

In another development, Fox (1991) is of the opinion that language can work as the chief means by which human beings communicate their feelings and thoughts to one another, and as such, it is viewed as a vital ingredient that holds societies together. This implies that the whole operation of the society depends upon it, and the greater contribution of man to the societal successes is the use of language. In support of the above, Ajayi (1998) asserts that language is used to express one's feelings or emotions either positively or negatively depending on the situation of things with one. In addition, he argues further that language is used in influencing people's behaviour, and to a greater extent, an instrument of making human cooperation a possibility.

Language as a national phenomenon to Nigeria like any other society has indigenous languages as her means of social engineering and interaction. Nigeria as a multilingual society had many languages spoken across the nation. Numerically, Greenberg (1971) puts Nigeria indigenous languages at two-hundred and fortyeight (248) while Bangbose (1976) approximately puts it at four-hundred (400). For further classification of indigenous languages, Oyedele (1997) argues that indigenous languages such as Igbo, Hausa, Yoruba, Ebira, Edo, Tiv, Fulfulde, among several others are the languages which groups of people consider to be spoken by the inhabitants of particular areas acquired in their early years and which normally become their natural means or instrument of thought and communication. In line with the above argument, Ugbala (1981) argues that any race or community which does not uphold and protect her language is woefully dead, helpless and hopeless, and can never survive the grave.

However, the advent of a foreign language (English, the Whiteman's language) reared its ugly head in the West African such-region particularly Nigeria. This foreign language inadvertently functions as the official language of the country and as the most convenient lingua franca amongst the various speech communities in the country. It serves the important role of unifying factor, providing a common vehicle of communication for the more than one-hundred million (100 million) speakers of diverse language in the areas of commerce, politics, administration, education, mass media and national and international communications (Oke 2000). In a situation like this where the indigenous language is also accepted for most transactions locally the need to attain a reasonable level of proficiency in the language is needed, this is the case if the Whiteman's language (English) in Nigeria. Basically in the absence of any indigenous language emerging as a chosen or recognized national language, the English language therefore continues to perform this role in additional to other numerous functions. Better still, the global the adoption of English as international medium of communication, an acknowledged language of science and technology as well as a universal medium of business transaction, is a very prestige that had never been enjoyed by any other language in Nigeria (Oke 2000)

Similarly, Obayan (1982) observes that English language had consolidated its domineering influence on, and has more non-indigenous languages (Arabic and French) which are also spoken in Nigeria. However, in spite of its functional roles and significant status in Nigeria, its acquisition still remains largely inadequate as certain errors are identifiable with particular linguistic groups or societies representing various ethnic groups in the Nigeria country. Many of such errors are purely interlingua in nature which manifest largely as a result of mother tongue interference, thus giving rise to many varieties of "English" as seen in Nigeria. These varieties include the Northern English variety", the "Southern English variety", the Educated English variety", the "Non-educated English variety," the "Incipience Bilingual English variety," the Market place English variety" and the "Nigerian Pidgin English variety," among several others. It could therefore be inferred that the recognition and importance attached to English language in Nigeria seems to have pushed and relegated all Nigerian indigenous languages to the lowest ebb, even though only a few members of the Nigerian people could speak the standard British English (SBrE).

\section{REVIEW OF LITERATURE ON Trilingualism AND Nigerian National Language Policy}

A great deal of attention had been drawn to third language learning and acquisition based on the 
growing need to be competent in language used in wider communication as well as to the exigencies of globalisation (Cenoz and Genesee, 1998), just as Clyne (1997) posits that this will encourage people to have another language of significance in their region, and an international language" besides their first language. Cenoz and Genesee (1998) assert further that in general, the process of acquiring several nonnative languages (i.e. multilingual acquisition) and the final result of this process (multilingualism) have relatively received attention in the scientific research in comparison to second language acquisition and bilingualism. In Nigeria, the National Language Policy formulated in 1977 and revised in 1981, 1998 and 2004 respectively assigns to English language the role of serving as the language of instruction from the fourth year of a six-year primary course to the tertiary level. In addition, English is to be taught as a school subject right from the first year of primary education. In the policy, the Nigerian constitution had a clause which recognises one of Hausa, Igbo and Yoruba (the languages of the larger ethnic groups in Nigeria) as an additional language of official proceedings in the federal legislature in addition to English as soon as the implementation is feasible (Banjo, 1996). In effects, Nigerian secondary school students are encouraged to learn one of these three Nigerian languages in addition to their mother tongues and English, if one of the three languages is not their mother tongue. Supporting the above position Udofot (2000) and Ker (2002) observe the implications these imposed "bilingualism, trilingualism and quadrilingualism" and the effects on the Nigerian child. They argue further that a language policy that singles out three languages for special attention is anything but fair and is therefore at variance with the tenet of equal educational opportunities entrenched in the National Policy on Education. While a child, speaking a major language can comfortably handle two languages e.g. (Hausa and English), his own mother tongue and English, a child speaking a minority language will have to grapple with three: his own mother tongue, a major language and English (e.g. Eluto, Igbo and English).

The concept of bilingualism seems at first to be non-problematic, just as Webster Dictionary (1961) sees bilingual as having or using languages especially as spoken with the fluency characteristics of a native speaker; a person using two languages especially habitually and with control like that of native speakers, as well as the constant oral use of two languages. This definition of bilingualism is applicable to trilingual people. In other words, trilingual people are those with the capability of perfect mastering over three languages. Similarly, Hoffmann (1999) argues that trilingualism means the presence of three languages in one speaker since the aim of learning a second language is to reach the level of bilinguality or trilinguality or more, a better understanding of the modus operandi involved in the development of bilinguality or trilinguality should help us to have a clear view of the second language learning and acquisition.

However, these national policies cannot be said to be fully in operation, for instance, in urban primary schools instructions are given in English right from the first year of primary education while the instantaneous switch to English in the fourth year of primary education hardly operates fully in the primary schools in the rural areas. Also the learning of another Nigerian language in addition to the mother tongue hardly operates even in Federal Government Schools because of the difficulties of having teachers; difficulties that may not be real. Though the language (English) is as old as the nation, it is still regarded as a foreign language and as a result, it is unable to perform all the functions expected from it. In another development, instead of the English language to unite Nigerians in all sense of life, reverse is the ease because not all the Nigeria people understand the language. Oke (2000) argues that at the vocabulary level, many acronyms such as INEC (Independent National Electoral Commission), ECOMOG (ECOWAS Monitoring Group), among others are being coined to express present political situation. As well, we have some expressions like "transition programme, interim government, hidden agendas, stepping aside, annulment," among several other expressions are all posing danger to the unity of the country. By inference, the above assertion connotes the wise saying that "a borrowed dress is usually oversized or undersized, this is true of English language visea-vis its functions in Nigeria. Since it is a foreign/borrowed language, it had not solved our problems rather it creates more problem for the country.

Right from the period of the coming of English as an educational instructional medium, the school system had greatly concentrated on two 
major lingua Franca in the continent of African sub-region. English and French are shared and used by the countries that fall within the purview of the two colonies. Nigeria as a British colony (Anglo-phone), uses English as her educational instructional medium while other countries that fall within the colonial purview of the France (Franco-phone) use French as their educational instructional medium.

\section{NeED FOR THE THREe MAJOR IndigenOUS LANGUAGES AS NATIONAL LANGUAGE}

The Nigerian languages have suffered a deadly blow in the hands of the white colonial masters who invaded Africa in desperate search for colonies. Based on this, Africans, including Nigerians were forced to see both their mother tongues and cultures as bush, primitive and worthless things that must be abandoned. The fervent implication of this "big time" mistake for Nigeria is the present scientific, technological, economic and political backwardness, upon which it is strongly asserted that except the Nigeria country subjugates the Whiteman's culture and language, then reverses to the Nigerian languages, her hope of political, economic scientific and technology developments will forever remain a mirage. Linguistically, Ebika (1988) posits that "an awareness" that people think first in (the) mother tongue and (that) mother tongue is concrete, intimate and long lasting, will not only enhance their appreciation of the Nigerian language but will enhance easy acquisition of the second language which will accelerate development of technology, science politics and economics. To further strengthen the importance of national language(s), Ebika (1988) and Oke (2000) are of the opinion that no technologically advanced country, be it Japan, France, Italy, America, Germany, Britain or China arrived at that stage with other people's language. This implies that all the advanced countries of the world today adapted their own indigenous or native languages to the scientific and technological developments.

As well, Bello (2011), by way of trying to move abreast with globalisation, the Nigerian Federal Government seems to have come with terms about the overwhelming importance of Nigerian languages in this scientific and technological era when it states in section eight of the National Policy on Education that:

In additional to appreciating the importance of language in educational process and as a means of preserving people's cultures, the government considers it to be in the interest of national unity that each child should be encouraged to learn one of the three major languages other than his own mother tongue(p.9).

It could therefore be inferred that for national development and technological evaluation, the Nigerian indigenous languages should be used as social engineering and vehicle of communication. The three major Nigerian indigenous languages are Hausa, Igbo and Yoruba. They are regarded as "the major" because of the teaming populace/population of the people that speak these three major languages. To make this a reality, the dictates of the national policy on education must be viewed seriously when it states that:

...each child should be encouraged to learn one of the three major languages other than his own mother tongue (p.9).

One of the goals of the policy is to promote multilingualism in the school system. This approach is in consonance with the current thinking of some bilinguals who are involved in the promotion of indigenous languages in multiethnic societies. The reasons for the promotion of indigenous languages in the education system is based on the assumption that a local language is the best medium of education because the child's mother tongue or the language of the child's immediate community is an effective link between home and school, which implies that the indigenous language forms that base, or the foundation for second language (L2) and third language (L3) respectively. The language of the immediate community is also an integral component of the child's culture. This indigenous language fosters bilingualism/ trilingualism (Oyeyemi 2001).

As recommended in the national policy on education (N.P.E., 1989), the promotion of Nigerian languages for nation-building and effective education is expected to be carried out in three ways:

i. The medium of instruction at the pre-primary level should be principally the mother tongue or the language of the immediate community. The same thing applies to the first three years of the primary level.

ii. The second language policy says that each child should be encouraged to learn one of the three major Nigerian languages (Igbo, Hausa, and Yoruba). 
iii. The third language policy prescription is on adult education programme. To make sure that the above cited prescription are properly implemented, the policy stipulates that the orthography of many Nigerian languages should be developed and appropriate textbooks in Nigerian languages be produced.(From the aforementioned policy, it could be inferred that the mother tongue or the language of the immediate community, if well internalised, will form the bedrock for L2 or L3, thus making it easier to learn other languages). By extension, this policy unconsciously promotes bilingualism or trilingualism among learners, thus meaning that first language (L1) promotes L2, then L2 or both exigencies in L1 and L2 will facilitate L3. Oyeyemi (2001) contends further that by implication if our young secondary school boys and girls know that they have to learn another Nigerian language apart from their mother tongue, they would be motivated to go outside their immediate linguistic milieu. This will effect great mobility among teachers, as teachers will be able to move to areas other than their own linguistic environment, thus redistributing teachers and negating the imbalance in teachers' production in Nigeria.

\section{HoPe ON Nigerian LANGUAGES AS NATIONAL LANGUAGES}

It is very pertinent to surmise here that all Nigerian languages can perform the same task as English language or any other foreign language(s). Oke (2000) opines that the three major Nigerian languages of Hausa, Igbo and Yoruba passed through selection, codification, elaboration and acceptance of linguistic norms. Even though Owaseye 91996) argues that inadequate lexical items for generalization and conceptualisation of scientific and technological thoughts will constitute the greatest problems in using the Nigerian languages, this problem will only last a short time as it is believed that "a journey of one million miles begins with a step", implying that whatever apparent handicaps that the Nigerian languages may have in moving abreast with scientific and technological challenges would only be momentary and temporal.

In support of the assertion above, Oluwatusin (1997) submits that "the Yoruba language since 1970 had aggressively tacked and resolved its language standardisation issues which strongly bordered on orthography, the dialect, the numeration and the Meta-language. The result of this effect can be surmised, as seen in the emergence of Yoruba names for many concepts in modern science and technology. Examples are:

\begin{tabular}{|c|c|c|}
\hline S.no & English & Yoruba \\
\hline 1 & loudspeaker & ero amohunke \\
\hline 2 & refrigerator & ero amu omi tutu \\
\hline 3 & bomb & ado oloro \\
\hline 4 & $\begin{array}{c}\text { Science and } \\
\text { technology }\end{array}$ & imo ero \\
\hline 5 & Tap water & omi ero \\
\hline 6 & table & tabili \\
\hline 7 & school & ile ikekoo (ile iwe) \\
\hline 8 & student & omo ile akekoo (omo ile iwe) \\
\hline 9 & bed & ibusun \\
\hline 10 & car & oko ayokele, etc \\
\hline
\end{tabular}

The fact that Nigerian languages of Hausa, Igbo and Yoruba can stand the test of time having passed through selection, codification, elaboration and acceptance of linguistic norms is enough hope for science and technology, hence, all of these big three languages can have various dialectical names for certain concepts in English language such as:

Table1. Nigeria's indigenous names for concepts in English language

\begin{tabular}{|c|c|c|c|c|}
\hline S/N & English & Hausa & Igbo & Yoruba \\
\hline 1 & train & $\begin{array}{c}\text { girigin } \\
\text { kasa }\end{array}$ & $\begin{array}{c}\text { ugbo } \\
\text { oloko }\end{array}$ & oko oju irin \\
\hline 2 & internet & yanargizo & $\begin{array}{c}\text { Igweosiso } \\
\text { intanet }\end{array}$ & ero ayelukara \\
\hline 3 & computer & $\begin{array}{c}\text { nauran } \\
\text { komputa }\end{array}$ & $\begin{array}{c}\text { igwe } \\
\text { komputa }\end{array}$ & $\begin{array}{c}\text { ero ayarabi } \\
\text { asa }\end{array}$ \\
\hline 4 & radio & $\begin{array}{c}\text { akwatin } \\
\text { radio }\end{array}$ & redio & $\begin{array}{c}\text { ero } \\
\text { asoromagbesi }\end{array}$ \\
\hline 5 & telephone & waya & ekwenti & $\begin{array}{c}\text { ero ibara eni } \\
\text { soro }\end{array}$ \\
\hline 7 & aeroplane & $\begin{array}{c}\text { giriginsa } \\
\text { mah }\end{array}$ & ugbo elu & $\begin{array}{c}\text { oko } \\
\text { ofurufu/baluu }\end{array}$ \\
\hline 8 & $\begin{array}{c}\text { medical } \\
\text { doctor }\end{array}$ & likita & $\begin{array}{c}\text { dokita } \\
\text { ahuike }\end{array}$ & $\begin{array}{c}\text { onisegun } \\
\text { oyinbo }\end{array}$ \\
\hline 9 & $\begin{array}{c}\text { photogra } \\
\text { pher }\end{array}$ & $\begin{array}{c}\text { mehoto } \\
\text { akwatin }\end{array}$ & $\begin{array}{c}\text { onye ose } \\
\text { foto }\end{array}$ & $\begin{array}{c}\text { oluyaworan, } \\
\text { ero imohun }\end{array}$ \\
\hline 10 & television & telebijin & $\begin{array}{c}\text { igwe } \\
\text { onyoyo }\end{array}$ & maworan, etc. \\
\hline
\end{tabular}

Source: Contact with native speakers of the languages

All the above however, do not mean that all the lexical problems of modernisation have been surmounted, a quite number of difficulties still exists, but still, this attempt could be regarded as a very good start and hope for more 
improvement, after all, a journey of one million miles begins with a step,

If the big three Nigerian indigenous languages are selected as national language, then the Nigerian national language would be categorised thus:

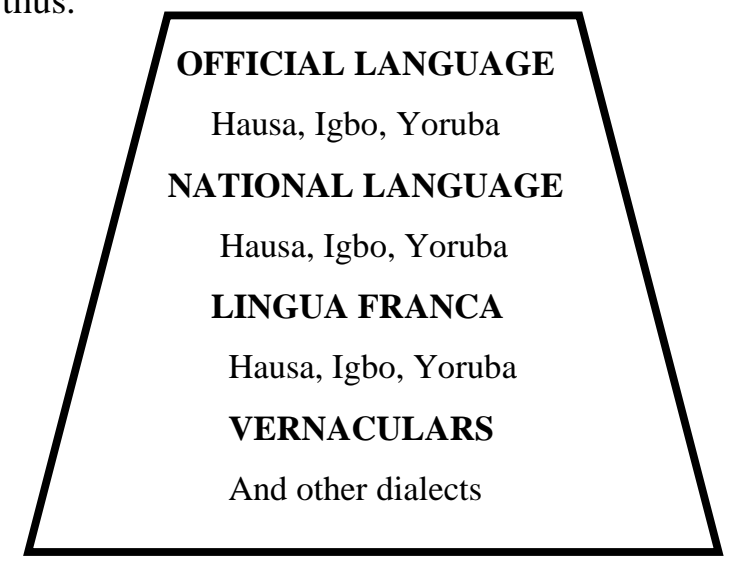

Fig1. Researcher-designed language hierarchy for Nigeria

The above would indicate that Hausa, Igbo and Yoruba featured predominantly at all levels of official language, national language, lingua franca and vernaculars if Nigerian indigenous languages are used as lingua franca. However, Ezikeojiaku (2002) posits that there is not real lingua franca for the whole country, Nigeria, the nearest one to it being Nigerian Pidgin English. However, there are regional lingua franca i.e. Hausa in the North, Igbo in the East and Yoruba in the West. These languages have been described by Brann (1986) as the decamillionaires (that is, language spoken by more than 10 million people or (demolects). Brann also groups other Nigeria languages as the millionaires, that is the languages spoken by more than one million people or (choralects), the centimils, that is, languages spoken by more than, 100,000 people or (ethnolects); and the minorities, that is the languages spoken by less than 100,000 people. Brann (1986) asserts further that there are in Nigeria three (3) decamillionaires, twelve (12) millionaires, about fifty (50) centimils and all the others are minorities. In support of the above, Agheyisi (1986) in Ezikeojiaku (2002) posits that the minorities, which she subsumes under minor languages, number about three hundred and ninety (390) and are spoken by about $20 \%$ of the total population of the nation.

\section{Statement of The Problem}

The presence of English language in Nigeria and the prestige accorded it has made it to continue to enjoy a prominent position in the political programmes of this largest black African nation, Nigeria. However, in spite of its significance, status and all importance in Nigeria, its acquisition still remains largely inadequate. It is observed that merit is usually scarified for mediocrity simply because there is yet to emerge a national language that can unite the various diverse groups indigenously for meaningful progress and technological development, thus sacrificing Nigerian indigenous languages for English language. For this reason, Gowling (1967) observes that:

Political and social mishaps which have already marred some of the steps taken in recent years would not have happened if the strength of the local languages as means of communication in respect of political, economic and social changes has been realized (p.17).

Lack of a common local language has rendered it very impossible to establish an efficient network of social, political interaction and communication throughout the country. This accounts majorly for the real reason why communication breakdown between the government and her people is always easy thereby giving chances for tribalists and other enemies of progress to cause and mislead the people. As well, this also inhibits the communication of new information, new ideas, political ideologies and techniques from the government to the masses, and consequently, slowing down the face of economic political, social, technological, scientific and cultural development of the country. By this, there is a need to perfect indigenous languages to function as national languages having passed through linguistic norms. The multi-ethnic situation in Nigeria and the consequent emotional feeling of ethnic identity and fear of marginalisation of the less populous ethnic groups which favoured the presence for English because of its neutrality of colonial origin notwithstanding.

\section{Purpose OF THE Study}

The purpose of the study is to investigate the relevance of monolingualism on trilingualism and achievement in language learning by English students of Nile University of Nigeria, Abuja, Nigeria.

\section{RESEARCH QUESTIONS}

The following research questions are drawn to guide the study: 
Relevance of Monolingualism on Trilingualism and Achievement in Language Learning among English Students of Nile University of Nigeria, Abuja, Nigeria

1. What is the grammatical performance of monolingual learners of English?

2. What is the fluency (reading) performance of the monolingual learners of English?

3. What is the grammatical performance of the bilingual learners of English?

4. What is the fluency (reading) performance of the bilingual learners of English?

5. What is the grammatical performance of the trilingual learners of English?

6. What is the fluency (reading) performance of the trilingual learners of English?

\section{RESEARCH HYPOTHESES}

The following research hypotheses are generated for testing in this study:

1. There is no significant difference between grammatical performance of monolingual learners of English and grammatical performance of bilingual learners of English.

2. There is no significant difference between oral reading performance of monolingual learners of English and oral reading performance of bilingual learners of English.

3. There is no significant difference between grammatical performance of monolingual learners of English and grammatical performance of trilingual learners of English

4. There is no significant difference between oral reading performance of monolingual learners of English and oral reading performance of trilingual learners of English.

5. There is no significant difference between

DATA ANALYSIS grammatical performance of bilingual learners of English and grammatical performance of trilingual learner of English

6. There is no significant difference between oral reading performance of bilingual learners of English and oral reading performance of trilingual learner of English.

\section{MeThodology}

This research was done with quantitative approach using descriptive survey. The population is all the students of English studies department of the Nile University of Nigeria, Abuja, Nigeria. A stratified random sample consists of thirty students: ten (10) monolingual learners of English, ten (10) bilingual learners of English and ten (10) trilingual learners of English. The location of the Nile University of Nigerian, Abuja provides unique milieu for this study in that it is located at where the three classes of monolingual, bilingual and trilingual learners of English could be easily obtained. The population is all the students studying English language as a foreign language. Their native languages are English, Hausa, Igbo, Turkishand Yoruba languages. Researcher-designed 20 item-questionnaire of English grammar and test of oral comprehension reading exercise were used for the study. Two experts from the English Studies department vetted the questionnaire for content validity of the instrument. The instrument was subjected to test re-test statistical technique, which yielded 0.54 reliability index at 0.05 alpha level of significance. Research questions 1-6 were answered using Mean and Standard Deviation statistics. Hypotheses 1-6 were analysed using t-test statistics.

Table2. Frequency counts and percentage distribution of grammatical and oral reading performance of monolingual, bilingual and trilingual learners of English

\begin{tabular}{|c|c|c|c|c|c|c|}
\hline S.no & \multicolumn{2}{|c|}{ MONOLINGUAL L.E. } & \multicolumn{2}{|c|}{ BILINGUAL L.E. } & \multicolumn{2}{c|}{ TRILINGUAL L.E. } \\
\hline & Gra. \% & Oral R. \% & Gra. \% & Oral R. \% & Gra. \% & Oral R. \% \\
\hline 1. & $15(75 \%)$ & $11(55 \%)$ & $17(85 \%)$ & $11(55 \%)$ & $18(90 \%)$ & $12(60 \%)$ \\
\hline 2. & $15(75 \%)$ & $17(85 \%)$ & $17(85 \%)$ & $13(65 \%)$ & $19(95 \%)$ & $11(55 \%)$ \\
\hline 3. & $12(60 \%)$ & $15(75 \%)$ & $16(80 \%)$ & $15(75 \%)$ & $19(95 \%)$ & $12(60 \%)$ \\
\hline 4. & $18(90 \%)$ & $15(75 \%)$ & $18(90 \%)$ & $12(60 \%)$ & $18(90 \%)$ & $12(60 \%)$ \\
\hline 5. & $18(90 \%)$ & $18(90 \%)$ & $16(80 \%)$ & $10(50 \%)$ & $17(85 \%)$ & $14(70 \%)$ \\
\hline 6. & $18(90 \%)$ & $12(85 \%)$ & $16(80 \%)$ & $10(50 \%)$ & $16(50 \%)$ & $15(75 \%)$ \\
\hline 7. & $11(55 \%)$ & $12(60 \%)$ & $17(85 \%)$ & $10(50 \%)$ & $16(50 \%)$ & $15(75 \%)$ \\
\hline 8. & $16(80 \%)$ & $18(90 \%)$ & $18(90 \%)$ & $15(75 \%)$ & $18(90 \%)$ & $15(75 \%)$ \\
\hline 9. & $15(75 \%)$ & $18(90 \%)$ & $19(95 \%)$ & $16(80 \%)$ & $17(85 \%)$ & $16(80 \%)$ \\
\hline 10. & $17(85 \%)$ & $18(90 \%)$ & $18(90 \%)$ & $11(55 \%)$ & $17(85 \%)$ & $16(50 \%)$ \\
\hline 11. & $11(55 \%)$ & $12(60 \%)$ & $10(50 \%)$ & $13(65 \%)$ & $19(95 \%)$ & $16(80 \%)$ \\
\hline 12. & $14(75 \%)$ & $15(75 \%)$ & $15(75 \%)$ & $11(55 \%)$ & $19(95 \%)$ & $16(80 \%)$ \\
\hline 13. & $15(75 \%)$ & $13(65 \%)$ & $16(80 \%)$ & $12(60 \%)$ & $18(90 \%)$ & $13(65 \%)$ \\
\hline
\end{tabular}


Relevance of Monolingualism on Trilingualism and Achievement in Language Learning among English Students of Nile University of Nigeria, Abuja, Nigeria

\begin{tabular}{|c|c|c|c|c|c|c|}
\hline 14. & $12(60 \%)$ & $14(70 \%)$ & $16(80 \%)$ & $11(55 \%)$ & $18(90 \%)$ & $12(60 \%)$ \\
\hline 15. & $12(60 \%)$ & $13(65 \%)$ & $18(90 \%)$ & $13(65 \%)$ & $19(95 \%)$ & $12(60 \%)$ \\
\hline 16. & $19(95 \%)$ & $13(65 \%)$ & $18(90 \%)$ & $13(65 \%)$ & $17(85 \%)$ & $13(65 \%)$ \\
\hline 17. & $18(90 \%)$ & $15(75 \%)$ & $18(90 \%)$ & $13(65 \%)$ & $17(85 \%)$ & $12(60 \%)$ \\
\hline 18. & $16(80 \%)$ & $15(75 \%)$ & $18(90 \%)$ & $11(55 \%)$ & $16(50 \%)$ & $12(60 \%)$ \\
\hline 19. & $16(80 \%)$ & $10(50 \%)$ & $18(90 \%)$ & $12(60 \%)$ & $18(90 \%)$ & $12(60 \%)$ \\
\hline 20. & $16(80 \%)$ & $15(75 \%)$ & $18(90 \%)$ & $13(65 \%)$ & $16(80 \%)$ & $15(75 \%)$ \\
\hline Average & $\mathbf{1 5 . 2}$ & $\mathbf{1 4 . 7}$ & $\mathbf{1 6 . 8 5}$ & $\mathbf{1 2 . 2 5}$ & $\mathbf{1 7 . 6}$ & $\mathbf{1 3 . 5}$ \\
\hline
\end{tabular}

Key: Monolingual L.E. = Monolingual learners of English;

Bilingual L. E. = Bilingual learners of English;

Trilingual L.E. = Trilingual learners of English

Gra. $=$ Grammar

Oral $R .=$ Oral reading

Table 2 shows that the average of the monolingual learners of English in grammar and oral reading are 15.2 and 14.7 respectively. The average of the bilingual leaners of English in grammar and oral reading are 16.85 and 12.25 respectively, while the averages of trilingual learners of English in grammar and oral reading are 17.6 and 13.5 respectively. The analyses in table 2 show that the grammatical aspect of the monolingual, bilingual and trilingual learners of English are high with trilingual learners of English being the highest with an average of 17.6 out of 20.This is in agreement with Hoffmann (1999) who asserts that trilingual means the presence of three languages in one speaker, and since the aim of learning a second language is to reach the level of bilinguality or trilinguality or more, a better understanding of the modus operandi involved in the development of bilinguality or trilinguality should help us to have a clear view of the second language learning and acquisition.

On the other hand, the oral reading aspect of the monolingual, bilingual and trilingual learners of English are above average, while oral reading performance of bilingual learners of English is the lowest, though above average. This, however, negates the finding of Hoffmann (1999) that says since the aim of learning a second language is to reach the level of bilingual or trilinguality or more, a better understanding of the modus operadi involved in the development of bilinguality or trilinguality should help language learners to have a clear view of the second language learning and acquisition.

\section{Research Question 1}

What is the grammatical performance of the monolingual learners of English?
Table3. The grammatical performance of the monolingual learners of English

\begin{tabular}{|c|c|c|c|c|}
\hline $\mathbf{N}$ & $\begin{array}{c}\text { Obtainable } \\
\text { Score }\end{array}$ & Mean & $\begin{array}{c}\text { Standard } \\
\text { deviation }\end{array}$ & Decision \\
\hline 20 & 20 & 14.015 & 3.337 & Good \\
\hline
\end{tabular}

Result in table 3 indicates that grammatical performance of the monolingual learners of English was good.

\section{Research Question 3}

What is the oral reading performance of the monolingual learners of English?

Table4. The oral reading performance of the monolingual learners of English

\begin{tabular}{|c|c|c|c|c|}
\hline $\mathbf{N}$ & $\begin{array}{c}\text { Obtainable } \\
\text { Score }\end{array}$ & Mean & $\begin{array}{c}\text { Standard } \\
\text { deviation }\end{array}$ & Decision \\
\hline 20 & 20 & 12.656 & 4.639 & Average \\
\hline
\end{tabular}

Result in table 4 indicates that the oral reading performance of the monolingual learners of English was average.

\section{Research Question 4}

What is the grammatical performance of the bilingual learners of English?

Table5. The grammatical performance of the bilingual learners of English

\begin{tabular}{|c|c|c|c|c|}
\hline $\mathbf{N}$ & $\begin{array}{c}\text { Obtainable } \\
\text { Score }\end{array}$ & Mean & $\begin{array}{c}\text { Standard } \\
\text { deviation }\end{array}$ & Decision \\
\hline 20 & 20 & 14.776 & 3.376 & Good \\
\hline
\end{tabular}

Result in table 5 shows that the grammatical performance of the bilingual learners of English was good.

\section{Research Question 5}

What is the oral reading performance of the bilingual learners of English? 
Relevance of Monolingualism on Trilingualism and Achievement in Language Learning among English Students of Nile University of Nigeria, Abuja, Nigeria

Table6. The oral reading performance of the bilingual learners of English

\begin{tabular}{|c|c|c|c|c|}
\hline $\mathbf{N}$ & $\begin{array}{c}\text { Obtainable } \\
\text { Score }\end{array}$ & Mean & $\begin{array}{c}\text { Standard } \\
\text { deviation }\end{array}$ & Decision \\
\hline 20 & 20 & 13.331 & 4.253 & Average \\
\hline
\end{tabular}

Result in table 6 is an indicative of average oral reading performance of the bilingual learners of English.

\section{Research Questions 6}

What is the grammatical performance of the trilingual learners of English?

Table7. The grammatical performance of the trilingual learners of English

\begin{tabular}{|c|c|c|c|c|}
\hline $\mathbf{N}$ & $\begin{array}{c}\text { Obtainable } \\
\text { Score }\end{array}$ & Mean & $\begin{array}{c}\text { Standard } \\
\text { deviation }\end{array}$ & Decision \\
\hline 20 & 20 & 17.151 & 2.014 & V. Good \\
\hline
\end{tabular}

Result in table 7 is an indicative of very good grammatical performance of the trilingual learners of English.

\section{Research Question 7}

What is the oral reading performance of the trilingual learners of English?

Table8. The oral reading performance of the trilingual learners of English

\begin{tabular}{|c|c|c|c|c|}
\hline $\mathbf{N}$ & $\begin{array}{c}\text { Obtainable } \\
\text { Score }\end{array}$ & Mean & $\begin{array}{c}\text { Standard } \\
\text { deviation }\end{array}$ & Decision \\
\hline 20 & 20 & 12.651 & 4.635 & Average \\
\hline
\end{tabular}

Result in table 8 shows that oral reading performance of the trilingual learners of English was average.

The findings of the results in tables 2, 3, 4, 5, 6, and 7 are in line with the findings of Ebika (1988) that "an awareness" that people first think in (the) mother tongue and (that) mother tongue is concrete, intimate and tong lasting, will not only enhance their appreciation of the Nigerian languages, but will enhance easy acquisition of the second language which will accelerate development of technology science, politics and economics.

\section{Hypotheses TeSTING}

$\mathbf{H o}_{1}$ : There is no significant different between grammatical performance of monolingual learners of English and grammatical performance of bilingual learners of English
Table9. T-test analysis of the difference between grammatical performance of monolingual learners of English and grammatical performance of bilingual learners of English

\begin{tabular}{|c|c|c|c|c|c|c|c|}
\hline Variable & $\mathbf{N}$ & $\begin{array}{c}\text { Mea } \\
\mathbf{n}\end{array}$ & SD & DF & $\begin{array}{c}\text { Criti } \\
\text { cal t- } \\
\text { value }\end{array}$ & $\begin{array}{c}\text { Calcul } \\
\text { ated t- } \\
\text { value }\end{array}$ & $\begin{array}{c}\text { Decisio } \\
\mathbf{n}\end{array}$ \\
\hline $\begin{array}{c}\text { G.P. of } \\
\text { Monolin } \\
\text { gual }\end{array}$ & 20 & $\begin{array}{c}14.01 \\
5\end{array}$ & $\begin{array}{l}3.3 \\
37\end{array}$ & & & & $\begin{array}{c}\text { Ho1 } \\
\text { Accepte } \\
\mathrm{d}\end{array}$ \\
\hline $\begin{array}{c}\text { G.P. of } \\
\text { Bilingual }\end{array}$ & 20 & $\begin{array}{c}14.77 \\
6\end{array}$ & 3.3 & 18 & 2.056 & 1.830 & 76 \\
\hline
\end{tabular}

G.P. of monolingual $=$ Grammatical performance of monolinguals

G.P. of bilingual $=$ Grammatical performance of bilinguals

The analysis in table 9 is an indicative of less calculated $\mathrm{t}$-value of 1.830 than the critical $\mathrm{t}$ value of 2.086 at 0.05 alpha level of significance, as such, the null hypothesis that says that there is no significant difference between grammatical performance of monolingual learners of English and grammatical performance of bilingual learners of English in hereby accepted.

$\mathrm{Ho}_{2}$ : There is no significant difference between oral reading performance of the monolingual learners of English and oral reading performance of the bilingual learners of English

Table10. T-test analysis of the difference between oral reading performance of the monolingual learners of English and oral reading performance of bilingual learners of English

\begin{tabular}{|c|c|c|c|c|c|c|c|}
\hline Variable & $\mathbf{N}$ & $\begin{array}{c}\text { Mea } \\
\mathbf{n}\end{array}$ & $\mathbf{S D}$ & $\mathbf{D F}$ & $\begin{array}{c}\text { Critic } \\
\text { al t- } \\
\text { value }\end{array}$ & $\begin{array}{c}\text { Calculat } \\
\text { ed t- } \\
\text { value }\end{array}$ & $\begin{array}{c}\text { Decis } \\
\text { ion }\end{array}$ \\
\hline $\begin{array}{c}\text { O.R.P. of } \\
\text { Monoling } \\
\text { ual }\end{array}$ & 20 & $\begin{array}{c}12.6 \\
56\end{array}$ & $\begin{array}{c}4.6 \\
39\end{array}$ & & & & \\
\hline $\begin{array}{c}\text { O.R.P. of } \\
\text { Bilingual }\end{array}$ & 20 & $\begin{array}{c}13.3 \\
31\end{array}$ & $\begin{array}{c}4.2 \\
53\end{array}$ & 18 & 2.086 & 1.574 & $\begin{array}{c}\text { Ho2A } \\
\text { ccept } \\
\text { ed }\end{array}$ \\
\hline
\end{tabular}

O.R.P. of monolingual $=$ oral reading performance of monolinguals

O.R.P. of bilingual $=$ oral reading performance of bilinguals

The analysis in table 9 shows that the calculated $\mathrm{t}$-value of 1.574 is less than the critical t-value of 2.086 tested at 0.05 alpha level of significance, and so, the null hypothesis that says that there is no significant difference between oral reading performance of the monolingual learners of English and oral reading performance of the bilingual learners of English is accepted. 
Relevance of Monolingualism on Trilingualism and Achievement in Language Learning among English Students of Nile University of Nigeria, Abuja, Nigeria

Hoz: There is no significant difference between grammatical performance of monolingual learners of English and grammatical performance of trilingual learners of English

Table11. T-test analysis of the difference between grammatical performance of monolingual learners of English and grammatical performance of trilingual learners of English

\begin{tabular}{|c|c|c|c|c|c|c|c|}
\hline Variable & $\mathbf{N}$ & $\begin{array}{c}\text { Mea } \\
\mathbf{n}\end{array}$ & SD & $\begin{array}{c}\text { D } \\
\mathbf{F}\end{array}$ & $\begin{array}{c}\text { Critic } \\
\text { al t- } \\
\text { value }\end{array}$ & $\begin{array}{c}\text { Calculat } \\
\text { ed t- } \\
\text { value }\end{array}$ & $\begin{array}{c}\text { Decisi } \\
\text { on }\end{array}$ \\
\hline $\begin{array}{c}\text { G.P. of } \\
\text { Monolin } \\
\text { gual }\end{array}$ & 20 & $\begin{array}{c}14.01 \\
5\end{array}$ & $\begin{array}{c}3.33 \\
7\end{array}$ & & & & \\
\cline { 1 - 4 } $\begin{array}{c}\text { G.P. of } \\
\text { Bilingual }\end{array}$ & 20 & $\begin{array}{c}17.15 \\
1\end{array}$ & $\begin{array}{c}2.01 \\
4\end{array}$ & 18 & 2.086 & 2.030 & $\begin{array}{c}\text { Ho3 } \\
\text { Accep } \\
\text { ted }\end{array}$ \\
\hline
\end{tabular}

G.P. of monolingual $=$ grammatical performance of monolinguals

G.P. of trilingual = grammatical performance of trilinguals

The analysis in table 11 shows that the calculated t-value of 2.030 is less than the critical t-value of 2.086 tested at 0.05 alpha level of significance, and by this the null hypothesis that says that there is no significant difference between grammatical performance of monolingual learners of English and grammatical performance of trilingual learners is accepted.

$\mathrm{Ho}_{4}$ : There is no significant difference between oral reading performance of monolingual learners of English and oral reading performance of trilingual learners of English

Table12. T-test analysis of the difference between oral performance of monolingual learners of English and oral performance of trilingual learners of English

\begin{tabular}{|c|c|c|c|c|c|c|c|}
\hline Variable & $\mathbf{N}$ & $\begin{array}{c}\text { Me } \\
\text { an }\end{array}$ & SD & DF & $\begin{array}{c}\text { Critic } \\
\text { al t- } \\
\text { value }\end{array}$ & $\begin{array}{c}\text { Calcul } \\
\text { ated } t- \\
\text { value }\end{array}$ & $\begin{array}{c}\text { Decisio } \\
\text { n }\end{array}$ \\
\hline $\begin{array}{c}\text { O.R.P. of } \\
\text { Monoling } \\
\text { ual }\end{array}$ & 20 & $\begin{array}{c}12.6 \\
56\end{array}$ & $\begin{array}{c}4.63 \\
9\end{array}$ & \multirow[b]{2}{*}{18} & \multirow[b]{2}{*}{2.086} & \multirow[b]{2}{*}{1.973} & \multirow{2}{*}{$\begin{array}{c}\text { Ho4 } \\
\text { Accep } \\
\text { ed }\end{array}$} \\
\hline $\begin{array}{l}\text { O.R.P. of } \\
\text { Bilingual }\end{array}$ & 20 & $\begin{array}{c}12.6 \\
51\end{array}$ & $\begin{array}{c}4.63 \\
5 \\
\end{array}$ & & & & \\
\hline
\end{tabular}

O.R.P. of monolingual= oral reading performance of monolinguals

O.R.P. of bilingual $=$ oral reading performance of trilinguals

The result in table 12 proves that the calculated $\mathrm{t}$-value of 1.973 is less than the table t-value of 2.086 at 0.05 alpha level of significance, this is a pointer to the fact that the null hypothesis which states that there is no significant difference between oral reading performance of monolingual learners of English and oral reading performance of trilingual learners of English is upheld.

H0$_{5}$ : There is no significant difference between grammatical performance of bilingual learners of English and grammatical performance of trilingual learners of English

Table13. T-test analysis of the difference between grammatical performance of bilingual learners of English and grammatical performance trilingual learners of English

\begin{tabular}{|c|c|c|c|c|c|c|c|}
\hline Variable & $\mathbf{N}$ & $\begin{array}{c}\text { Mea } \\
\mathbf{n}\end{array}$ & SD & DF & $\begin{array}{c}\text { Criti } \\
\text { cal } \\
\text { value }\end{array}$ & $\begin{array}{c}\text { Calcula } \\
\text { ted } \\
\text { value }\end{array}$ & $\begin{array}{c}\text { Decrea } \\
\text { se }\end{array}$ \\
\hline $\begin{array}{c}\text { G.P of } \\
\text { bilinguals }\end{array}$ & 20 & $\begin{array}{c}14.7 \\
76\end{array}$ & $\begin{array}{c}3.3 \\
76\end{array}$ & & & & \\
\hline $\begin{array}{c}\text { G.P of } \\
\text { trilinguals }\end{array}$ & 20 & $\begin{array}{c}14.1 \\
51\end{array}$ & $\begin{array}{l}2.0 \\
14\end{array}$ & 18 & 2.086 & 1.005 & $\begin{array}{c}\mathrm{Ho}_{5} \\
\text { Accept }\end{array}$ \\
\hline
\end{tabular}

G.P. of bilinguals $=$ Grammatical performance of bilinguals

G.P. of trilinguals $=$ Grammatical performance of trilinguals

The result in table 13 is an indicative of less calculated t-value of 1.005 than critical $t$-value of 2.086, tested at 0.05 alpha level significance, hence, upholding the null hypothesis which says that there is no significant difference between grammatical performance of bilingual learners of English and grammatical performance of trilingual learners of English.

Hog: $_{6}$ There is no significant difference between oral reading performance of bilingual learners of English and oral reading performance of trilingual learners of English

Table14. T-test analysis of the difference between oral reading performance of bilingual learners of English and oral reading performance of trilingual learners of English

\begin{tabular}{|c|c|c|c|c|c|c|c|}
\hline $\begin{array}{c}\text { Variabl } \\
\text { e }\end{array}$ & $\mathbf{N}$ & $\begin{array}{c}\text { Mea } \\
\mathbf{n}\end{array}$ & SD & $\begin{array}{c}\mathbf{D} \\
\mathbf{F}\end{array}$ & $\begin{array}{c}\text { Critica } \\
\text { l value }\end{array}$ & $\begin{array}{c}\text { Calculat } \\
\text { ed value }\end{array}$ & $\begin{array}{c}\text { Decre } \\
\text { ase }\end{array}$ \\
\hline $\begin{array}{c}\text { ORP of } \\
\text { bilingua } \\
\text { ls }\end{array}$ & 20 & $\begin{array}{c}13.33 \\
1\end{array}$ & $\begin{array}{c}14.2 \\
53\end{array}$ & & & & \\
\hline $\begin{array}{c}\text { ORP of } \\
\text { trilingua } \\
\text { ls }\end{array}$ & 20 & $\begin{array}{c}12.65 \\
1\end{array}$ & $\begin{array}{c}4.63 \\
5\end{array}$ & 18 & 2.086 & 2.001 & $\begin{array}{c}\mathrm{Ho}_{6} \\
\mathrm{Acce} \\
\mathrm{pt}\end{array}$ \\
\hline
\end{tabular}

ORP of bilinguals $=$ Orals reading performance of bilinguals

ORP of trilinguals $=$ Oral reading performance of trilinguals

The result in table 14 as shown above is an 
indicative of less calculated t-value of 2.001 than the critical t-value of 2.086 at 0.05 alpha level of significance, thus, upholding the hypothesis which states that there is no significant difference between oral reading performance of bilingual learners of English and oral reading performance of trilingual learners of English.

\section{DISCUSSION}

Results in tables 2, 4 and 6 all indicate that grammatical performance of monolingual, bilingual and trilingual learners of English was good, while tables 3, 5 and 7 indicate that oral reading performance of monolingual, bilingual and trilingual learners of English was average. These results are in consonance with the assertion of Oyeyemi (2001) that one of the goals of the policy is to promote multilingualism in the school system. This approach is in consonance with the current thinking of some bilinguals who are involved in the promotion of indigenous languages in multi-ethnic societies. The reasons for the promotion of indigenous languages in the education system is based on the assumption that a local language is the best medium of education because the child's mother tongue or the language of the child's immediate community is an effective link between home and school, which implies that the indigenous language forms that base, or the foundation for second language (L2) and third language (L3) respectively. The language of the immediate community is also an integral component of the child's culture. These indigenous languages foster bilingualism/ trilingualism.

Similarly, the results of the tested hypotheses in tables 9-14 indicate that all the hypotheses were accepted because there was no significant difference between grammatical performance of monolingual, bilingual and trilingual learners of English, as well as no significance difference between oral reading performance of monolingual, bilingual and trilingual learners of English. These results agree with NEP (1989) that posits that the promotion of Nigerian languages for nation-building and effective education is expected to be carried out in three ways:

i. The medium of instruction at the pre-primary level should be principally the mother tongue or the language of the immediate community. The same thing applies to the first three years of the primary level.

ii. The second language policy says that each child should be encouraged to learn one of the three major Nigerian languages (Igbo, Hausa, and Yoruba).

iii. The third language policy prescription is on adult education programme. To make sure that the above cited prescription are properly implemented, the policy stipulates that the orthography of many Nigerian languages should be developed and appropriate textbooks in Nigerian languages be produced.(From the aforementioned policy, it could be inferred that the mother tongue or the language of the immediate community, if well intrnalised, will form the bedrock for L2 or L3, thus making it easier to learn other languages). By extension, this policy unconsciously promotes bilingualism or trilingualism among learners, thus meaning that first language (L1) promotes L2, then L2 or both exigencies in L1 and L2 will facilitate L3. Oyeyemi (2001) contends further that by implication if our young secondary school boys and girls know that they have to learn another Nigerian language apart from their mother tongue, they would be motivated to go outside their immediate linguistic milieu. This will effect great mobility among teachers, as teachers will be able to move to areas other than their own linguistic environment, thus redistributing teachers and negating the imbalance in teachers' production in Nigeria.

\section{CONCLUSION}

From the findings, it is therefore concluded that L1 literally is seen as monolingualism that aids L2, then L2 or the combination of L1 and L2 facilitate the learning of L3.

\section{RECOMMENDATIONS}

As a result of the findings and conclusion, it is therefore recommended among other things that:

1. Federal Government should look into the concept of multilingualism with a view to making it an achievable project for national and international intelligibility that would eventually promote national development;

2. The Federal Ministry of Education should enforce it that each Nigerian child should have a certificate of one of the Nigerian languages other than his own native or indigenous language, and make books in Nigerian languages cheaper and available in bookshops;

3. Parents should encourage their children to study the Nigerian languages and also read texts or books on Nigerian languages; 
Relevance of Monolingualism on Trilingualism and Achievement in Language Learning among English Students of Nile University of Nigeria, Abuja, Nigeria

4. Instructors in schools should also be made to learn other Nigerian languages to make their mobility possible and effective; and

5. Nigerian students should be motivated and encouraged to be willing to learn more national languages to facilitate students' mobility in Nigerians.

\section{REFERENCES}

[1] Areje, R.A. (1988) Yoruba Proverbs In Oke, J.O. (2000). Towards the Development of the three major Indigenous Languages as National Language in Nigeria.

[2] Oro Journal of Educational and Technological Studies Vol.2 (1 and 2).

[3] Banjo, A. (1996).An overview of the English language in Nigeria. Ibadan: Ibadan University Press.

[4] Brann, C.M. (1986). Mother tongue, other tongue, further tongue. Inaugural Lecture, University of Maiduguri

[5] Cenoz J and Genesee, F. (Eds.) (1998).Beyond Bilingualism: Multilingualism and Multilingual Education Clevedon: Multilingual Matters.

[6] Clyne, M. (1997). Some of the things Trilinguals do. International Journal of bilingualism, 1.95-116

[7] Ebika, U.S. (1998). Indigenous Language in Science and Technology the Nigerian

[8] Experience: B.A. Long Essay, School of Humanities, Imo University, Okigwe.

[9] Fox, A. (ed) (1991). Studying English literature: A guide for advancing Students.

[10] Otago, New Zealand: University of Otago Press

[11] Federal Government of Nigeria (1989).National Policy on Educational (Revised) NERC.

[12] Gowling, R.A. (1967). "The New Approach to Teaching of Literature in Secondary Schools" West African Journal of Education, X1 In Oke, J.O (2000). Towards the Development of the three Major Indigenous languages as National language in Nigeria.
[13] Oro journal of educational and technological studies vol.2 (1 and 2).

[14] Greenberg, J.H. (1971) Language, Culture and Communication. Standard: Standard University Press

[15] Hoffmann, C (1999). The Status of trilingualism in bilingualism". A Paper Presented in the International Conference on Trilingualism and Third Language Acquisition Innstruck, Australia.

[16] Ker, D. (2002). The choice of English as a National Language for Nigerian: A reevaluation. In Lawal, A. Isingo - Abanikhe, I and Ohia, I. (Eds)

[17] .Perspectives on Applied Linguistics in Language and Literature. Ibadan: Stirling Horden Publishers, pp.114- 128

[18] Obayan, P. (1982). Secondary English Teaching. Lagos: Macmillan

[19] Oke, O.J. (2000). Towards the Development of the Three Major Indigenous

[20] Languages as National Language in Nigeria. Oro Journal of Educational and Technological Studies Vol.2 (1 and 2).

[21] Oluwatusin, S. (1997).National Language: The Journey so far. Paper Presented at School of Languages Seminar, Federal college of Education, Okene

[22] Oyeyemi, S.O. (2001). Implication of the National Policy on Education on Language Teaching and Learning at the Primary School Level.

[23] Journal of Studies in Language and Literature.

[24] Piaget, J (1973). To understand is to Invent. New York: Grossman.

[25] Udofot, I. (2000). Bilingualism, trilingualism and quadrilingualism: The language situation of the Nigerian child. University of Uyo Journals of Women

[26] Academics (UJOWACS). I (1), 86-95.

[27] Webster, N. (1996). New International Dictionary England, Grand C. Miriam Co.

Citation: BELLO, Yekeen. "Relevance of Monolingualism on Trilingualism and Achievement in Language Learning among English Students of Nile University of Nigeria, Abuja, Nigeria." International Journal of Research in Humanities And Social Studies, vol 4, no. 6, 2017, pp. 9-20.

Copyright: () BELLO, Yekeen. This is an open-access article distributed under the terms of the Creative Commons Attribution License, which permits unrestricted use, distribution, and reproduction in any medium, provided the original author and source are credited. 